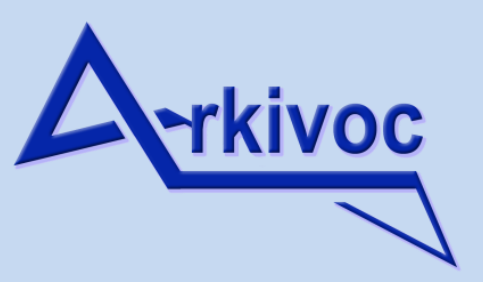

Archive for

Organic Chemistry
The Free Internet Journal

for Organic Chemistry
Paper

Arkivoc 2019, part vi, 416-430

\title{
Synthesis, characterization, antimicrobial activities and electrochemical behavior of new phenolic azo dyes from two thienocoumarin amines
}

Kamal S. D. Djeukoua, ${ }^{a}$ Emmanuel S. Fondjo, *a Jean-de-Dieu Tamokou, ${ }^{b}$ Joseph Tsemeugne, ${ }^{\text {a,f }}$ Peter F. W. Simon, ${ }^{\mathrm{C}}$ Appolinaire Tsopmo, ${ }^{\mathrm{d}}$ Francis M. M. Tchieno, ${ }^{\mathrm{e}}$ Steve E. Ekom, ${ }^{\mathrm{b}}$ Chancellin N. Pecheu, ${ }^{\mathrm{e}}$ Ignas K. Tonle, ${ }^{\mathrm{e}}$ and Jules-Roger Kuiate ${ }^{\mathrm{b}}$

a Laboratory of Applied Synthetic Organic Chemistry, Department of Chemistry, Faculty of Science, University of Dschang, P.O. Box 67 Dschang, Republic of Cameroon; ' Laboratory of Microbiology and Antimicrobial Substances, Department of Biochemistry, Faculty of Science, University of Dschang, PO Box 067 Dschang, Republic of Cameroon; 'Polymer Chemistry Laboratory, Faculty of Live Sciences, Rhine-Waal University of Applied Sciences, Campus Kleve, Marie-Curie Strasse 1, D-47533 Kleve, Germany; Department of Chemistry, Carlton University, Room 207D, Steacie Building 1125 Colonel By Drive K1S 5B6, Ontario, Canada +1-613-520-

260 Ext 3122; ${ }^{e}$ Laboratory of Electrochemistry and Chemistry of Materials, Department of Chemistry, University of Dschang, P.O. Box 67 Dschang, Cameroon; 'fDepartment of Organic Chemistry, University of Yaounde I, P.O. Box 812, Yaounde, Republic of Cameroon

E-mail: sopbue@yahoo.fr

Received 06-07-2019

Accepted 01-13-2020

Published on line $02-11-2020$

\section{Abstract}

The coupling reactions of diazotized thienocoumarin derivatives with $p$-acetaminophen, salicylic acid and acetylsalicylic acid gave four products in which the benzene ring of the phenolic reagents were primarily substituted by two 3-diazenyl-4H-thieno[3,4-c]chromen-4-one or 3-diazenyl-4-imino-4H-thieno[3,4c]chromene moieties. The newly prepared azo dyes were fully characterized based on their analytical and spectroscopic data. The electrochemical analysis of the novel azo dyes carried out on a glassy carbon electrode unequivocally further confirmed the assigned structures. The synthesized compounds tested for their antimicrobial activity using broth microdilution method, showed good activities.
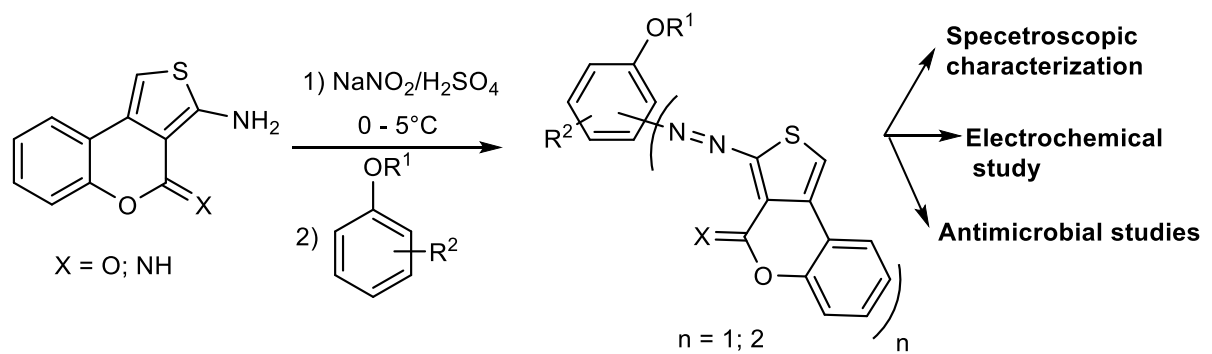

Keywords: Azo compounds, phenol derivatives, synthesis, characterization, redox studies, antimicrobial activity 


\section{Introduction}

The synthesis of organic dyes as nonlinear optical materials is an increasingly prolific research axis in the world. ${ }^{1-3}$ These materials are widely used in optical communication, information processing, frequency doubling and integrated optics. ${ }^{4-6}$ Nonlinear optical materials (NLO) have several advantages over inorganic materials used for the same reasons. We can thus name the great value of the nonlinear optical coefficient, the easy methods of synthesis and preparation, and the low costs. ${ }^{7}$

Heterocyclic azo dyes are used as better coloring agents in the textile industry. ${ }^{8}$ The applications of azo compounds in the electronic industry as colorimetric sensors, ${ }^{9}$ nonlinear optical (NLO) devices ${ }^{10,11}$ and liquid crystalline displays (LCDs) ${ }^{12}$ have been intensively investigated. This group of compounds has attracted much attention for their use as potential sensitizers for photodynamic therapy (PDT). ${ }^{13}$

The azo dyes containing the thiophenic ring have several advantages over other dyes, in particular due to their intense coloration effect. ${ }^{14,15}$

Electrochemical, photophysical and photochemical properties of azo molecules have been used to predetermine their reactivity or to confirm their structures. ${ }^{16,17}$ In a recent work, our group reported the electrochemical behavior of azo compounds containing hydroxyl group located at the ortho position of the azo group. ${ }^{18}$ In the present study, we extend our investigations to diazo dyes possessing different substituents in order to evaluate the influence of the substituent on the progress of the redox reactions. Indeed, another work has shown that the type of substituent on the aromatic ring of some azo compounds has an influence on the oxidation-reduction. ${ }^{19}$ The purpose of the present work was then to prepare and describe new azo compounds, to determine their degradation under electrochemical conditions, and finally to determine their antimicrobial properties.

\section{Results and Discussion}

\section{Chemistry}

The present investigation deals with the synthesis of novel azo compounds using thienocoumarins 2 as starting materials. The general preparation procedure is displayed in Scheme $1 .{ }^{20-22}$

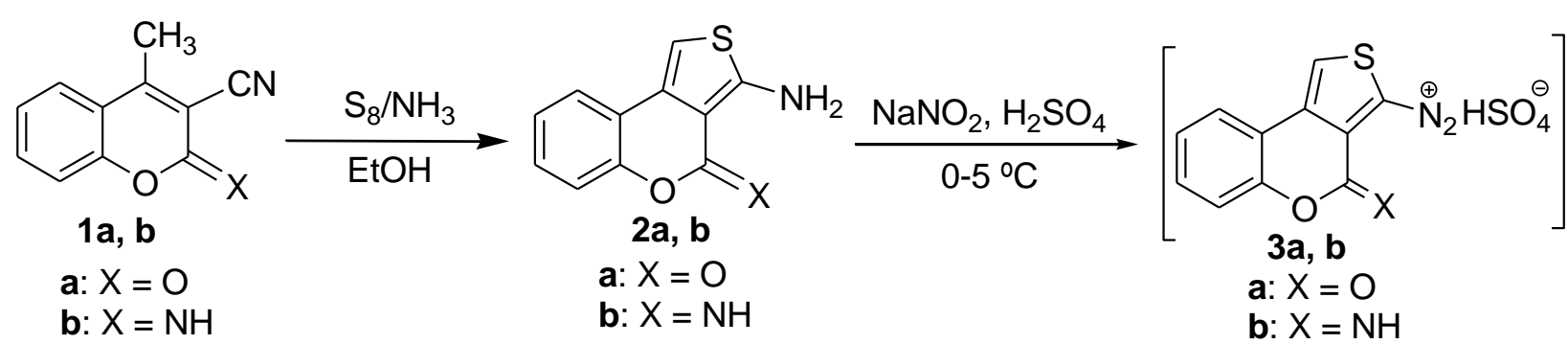

Scheme 1. Reactions' sequences to the in situ formed diazonium intermediates.

The thienyldiazonium ions $\mathbf{3}$ were readily synthesized by adding thienocoumarin $\mathbf{2}$ to nitrosyl sulfuric acid at $0-5^{\circ} \mathrm{C}$ according to literature. ${ }^{23}$ Diazonium ion 3 a was then coupled with three phenol derivatives namely salicylic acid (4a), p-acetaminophen (4b) and acetylsalicylic acid (4c) to yield compounds 5a-c (Scheme 2). 


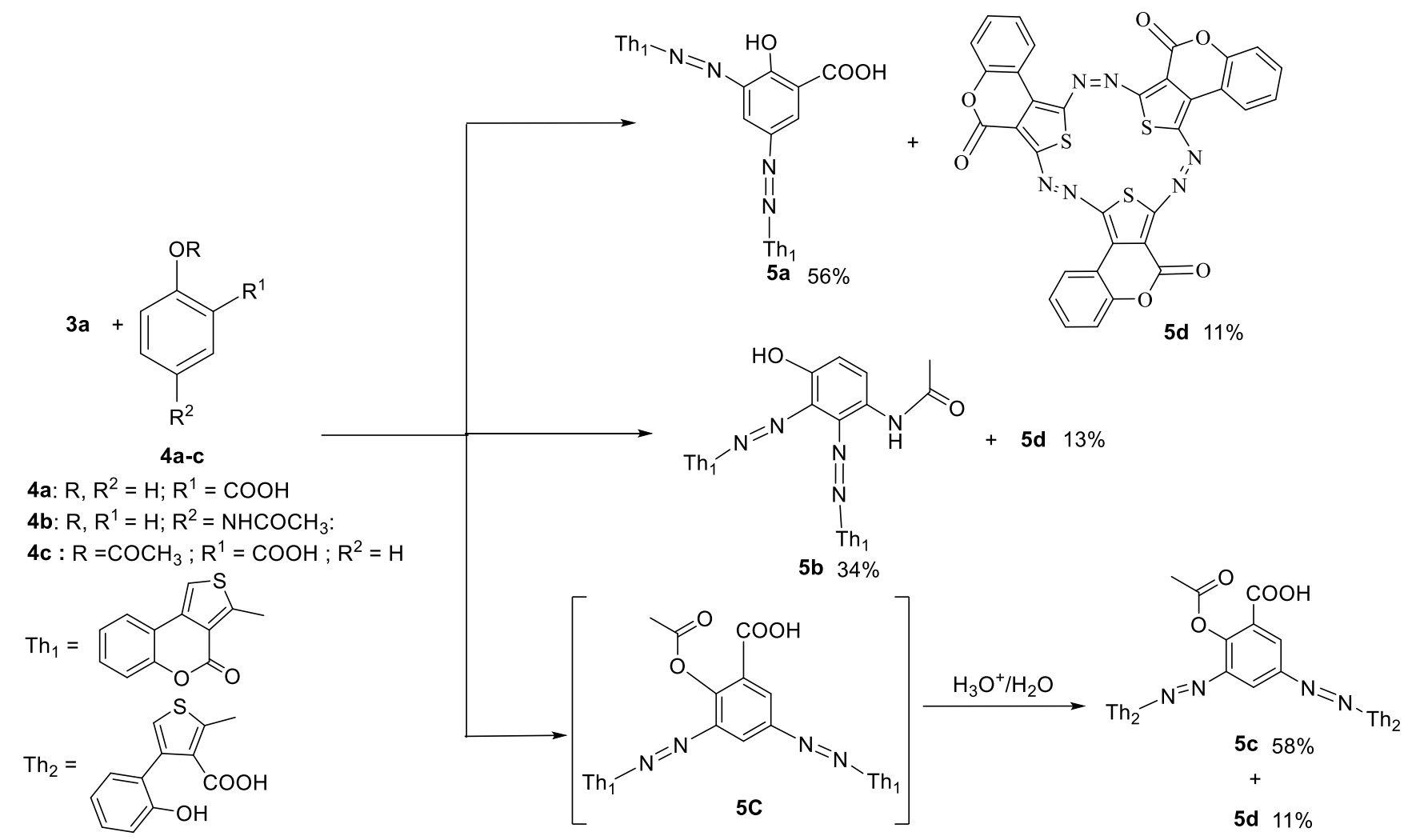

Scheme 2. Reactions' sequences to compounds 5.

The coupling of the in situ formed diazonium ion $\mathbf{3 b}$ with 2-acetyl salicylic acid in similar reactions' conditions gave compound $\mathbf{6}$ (Scheme 3 ) in good yield. It has to be pointed out, that compound $\mathbf{5 d}$ was found in all reactions mentioned as an additional product. This compound resulting from the cyclotrimerization of the intermediate 3-diazenyl-4H-thieno[3,4-c]chromen-4-one ion (3a), was previously reported. ${ }^{24}$ In the case involving the intermediate ion $\mathbf{3 b}$, the later might undergo oxidation of its imino group into the carbonyl function prior to the cyclotrimerization process. Alternatively $\mathbf{3 b}$ might first cyclize before the oxidation of the imino group into the carbonyl function occur.

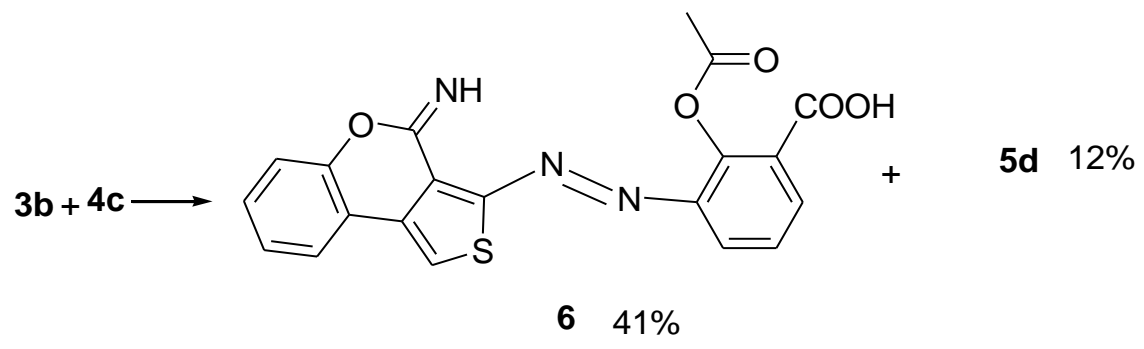

Scheme 3. Reaction sequence to compound 6.

The synthesized compounds 5 and $\mathbf{6}$ were characterized on the basis of their physical data and spectral analysis.

The infrared spectra of all the synthesized dyes showed intense bands between $3621-3277 \mathrm{~cm}^{-1}$ due to free and associated $\mathrm{OH}$ groups and other bands at $1733-1670 \mathrm{~cm}^{-1}$ which were assigned to the carbonyl groups. The FT-IR spectra also showed bands at $1490 \mathrm{~cm}^{-1}$, assigned to the $-\mathrm{N}=\mathrm{N}$ - linkage of the azo moieties. 
The ${ }^{1} \mathrm{H}$ NMR spectrum of compound 5a showed five sets of aromatic $\mathrm{Csp}^{2}-\mathrm{H}$ protons characteristic of the parent thiophene at $7.70\left(2 \mathrm{H}, \mathrm{s}, \mathrm{H}-\mathrm{1}^{\prime}\right.$ and $\left.\mathrm{H}-1^{\prime \prime}\right) ; 7.35\left(2 \mathrm{H}, \mathrm{dd}, \mathrm{H}-6^{\prime}\right.$ and $\mathrm{H}-6^{\prime \prime}, \mathrm{J}_{\mathrm{HH}} 6.8$ and $\left.1.1 \mathrm{~Hz}\right) ; 7.69(2 \mathrm{H}, \mathrm{ddd}$, $J_{H H} 7.5, J_{H H} 6.4$ and $1.5 \mathrm{~Hz}, \mathrm{H}-7^{\prime}$ and $\left.\mathrm{H}^{-7}{ }^{\prime \prime}\right) ; 7.39\left(2 \mathrm{H}\right.$, ddd, $J_{H H} 7.3, J_{H H} 6.9$ and $1.6 \mathrm{~Hz}, \mathrm{H}-8^{\prime}$ and $\left.\mathrm{H}-8^{\prime \prime}\right)$ and 8.80 $\left(2 \mathrm{H}, \mathrm{dd}, J_{H H} 7.5\right.$ and $1.7 \mathrm{~Hz}, \mathrm{H}-9^{\prime}$ and $\left.\mathrm{H}-9^{\prime \prime}\right)$. The signal of the salicylic acid group was found at $14.36 \mathrm{ppm}$. The positions of both parent thiophenic moieties on the phenolic ring were assigned based on the coupling constant observed between the only two remaining aromatic protons' signals at $7.72\left(1 \mathrm{H}, J_{H H} 1.2 \mathrm{~Hz}, \mathrm{H}-4\right)$ and $7.37\left(1 \mathrm{H}, \mathrm{d}, J_{H H} 1.2 \mathrm{~Hz}, \mathrm{H}-6\right)$.

The ${ }^{13} \mathrm{C}$ NMR spectrum exhibited 22 signals in agreement with the assigned structure $\mathbf{5 a}$. The DEPTspectrum indicates the presence of 12 hydrogenated carbons. Strong signals observed in this spectrum are considered to belong to the benzenic cycles of the parent thiophene moiety, since the signal of two hydrogenated thiophenic carbons were identified at 125.6 ppm. ${ }^{22-24}$ The signal of the carbonyl group of the carboxylic group was found at $185.1 \mathrm{ppm}$.

The structure of compound $\mathbf{5 a}$ is further strongly supported by its HRMS ESI+ mode, which shows the pseudo molecular ion peak at $\mathrm{m} / \mathrm{z} 607(1 \%)$ corresponding to $\left[\mathrm{M}-\mathrm{CO}_{2}+\mathrm{H}_{2} \mathrm{O}+\mathrm{K}^{+}\right]$and characteristic fragment ion peaks at $\mathrm{m} / \mathrm{z} 549\left(1 \%\right.$, cleavage of $\left.\mathrm{CO}_{2}\right), \mathrm{m} / z 493\left(1 \%\right.$, cleavage of $\mathrm{CO}_{2}$, then losses of both azoic bridge). The peaks at $m / z 413(1 \%), 360(19)$ and $270(100)$ were respectively attributed to the fragment ions $\left(\mathrm{M}+\mathrm{H}-2 \mathrm{~S}-2 \mathrm{~N} 2^{-}\right.$ $\left.\mathrm{CO}_{2}-\mathrm{H}_{2} \mathrm{O}\right)$, $\left(\mathrm{M}-\mathrm{N}_{2}-\mathrm{CO}_{2}-\mathrm{C}_{7} \mathrm{H}_{6} \mathrm{O}_{3}\right)$ and $\left(\mathrm{C}_{11} \mathrm{H}_{7} \mathrm{O}_{3} \mathrm{~N}_{2} \mathrm{SNa}\right)^{+}$.

As previously mentioned, in the case of compounds $\mathbf{5 c}$ we noticed the opening of the coumarin rings. ${ }^{23,26}$ We also noted that, as earlier described, these products result from multiple copulation of the diazonium moiety on the phenol derivative. ${ }^{27}$

Similar analysis as above was conducted on the basis of the available elemental and spectroscopic data for the structural assignments of compounds $\mathbf{5 b}, \mathbf{5 c}$ and $\mathbf{6}$.

\section{Redox behaviors of the azo dyes}

The cyclic voltammograms obtained for compounds $\mathbf{5 a - c}$ and $\mathbf{6}$ showed a quasi-reversible system (peaks I and II). This corresponds to the reduction of the pristine dye's azo functions to hydrazo functions. ${ }^{28,29}$ Further reduction is observed at peak III. This probably corresponds to the fragmentation of the hydrazo functions to form amine functions. Peak IV corresponds to the further reduction of one of the latter fragmentation products. Based on the foregoing discussion, the electrochemical mechanisms depicting the electrode phenomena are shown in Schemes 4-6. Since one of the hydrazo functions of compound $\mathbf{5 c}$ is highly hindered, its fragmentation probably takes place in two steps, with the less hindered function reduced first (scheme 5).

\section{Electrochemical reaction mechanisms of the studied azo dyes}

Compound 5a. Three distinct reduction peaks (II, III and IV) were observed for the electroreduction of azo dyes $\mathbf{5 a}$, the first one II due to the formation of the hydrazo product A1 (Scheme 4) which provide quasi reversible oxidation-reduction peaks I during reverse and subsequent forward scans due to the formation of oxidation product $\mathbf{5 a}$ and its subsequent reduction to compound $\mathbf{A} \mathbf{1}$. The second peak III, is due to the reduction of hydrazo-compound $\mathbf{A} \mathbf{1}$ to yield two amines $\mathbf{A} \mathbf{2}$ and $\mathbf{A} \mathbf{3}$ (Scheme 4). The third peak can therefore be attributed to the reduction of the carbonyl function of compound $\mathbf{A} \mathbf{2}$ to yield compound $\mathbf{A} 4$. 


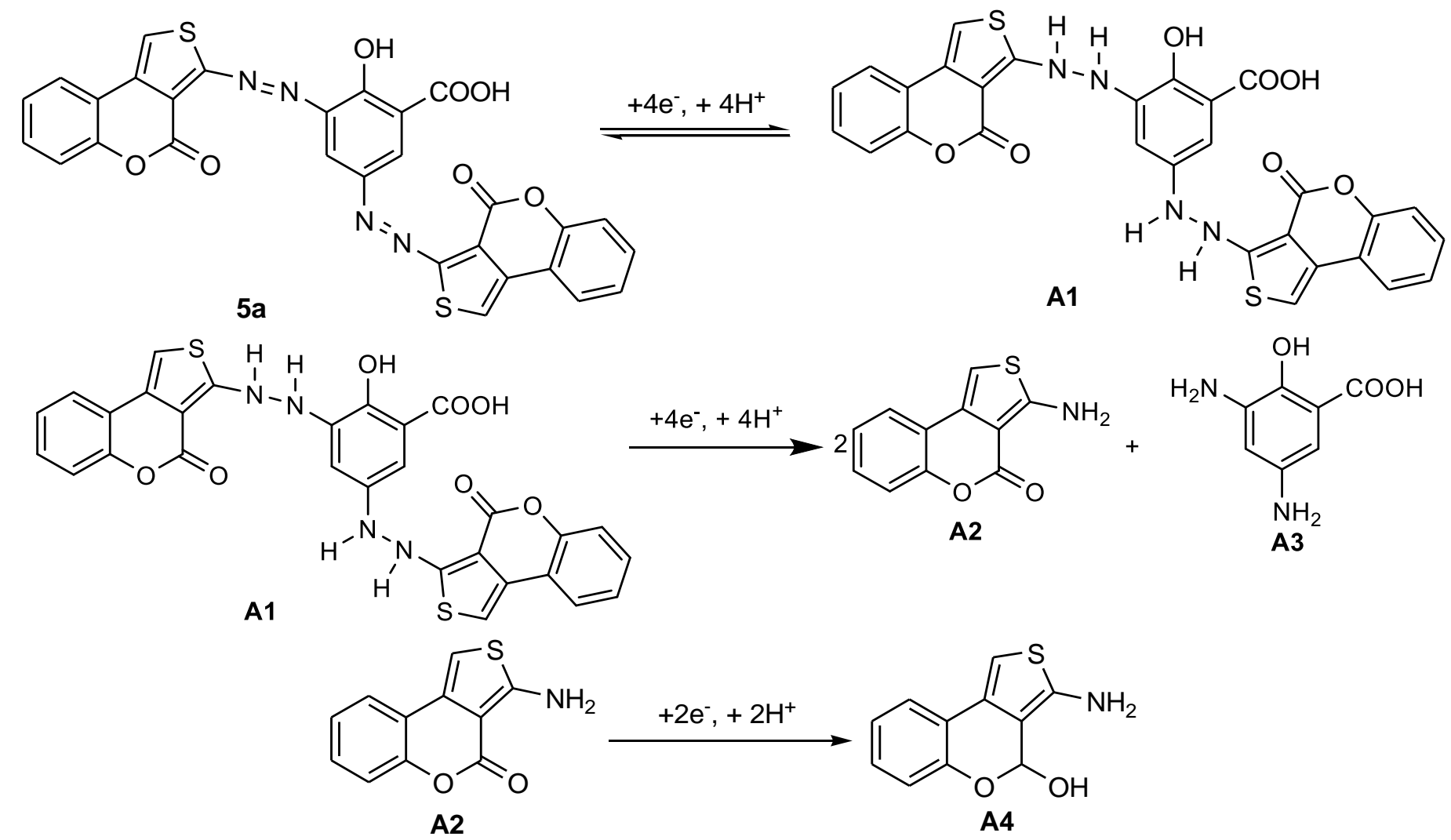

Scheme 4. Electrochemical reaction mechanism of $\mathbf{5 a .}$

Compound $\mathbf{5 b}$. The mechanistic details of the electrochemical oxidation and reduction of compound $\mathbf{5 b}$ are similar to those of compound $\mathbf{5 a .}$

Compound 5c. In the cyclic voltammograms of 5c, four peaks were recorded, of which three cathodic peaks (II, III and IV) in the forward scan and one anodic peak (I) in the reverse scan, indicating the quasi-reversible electrochemical nature of the dye. The anodic peak only appeared in the subsequent scan after the reduction step.

The first peak can be attributed to the reduction of the two $-\mathrm{N}=\mathrm{N}-$ bridges (Scheme 5 ) to yield the hydrazo intermediate $\mathbf{B 1}$ which in turn is reduced to give compound 5c during reverse and subsequent forward scan. The second peak III, is due to the reduction of one hydrazo bond of compound B1 particularly the hydrazo bond adjacent to the electron-donating groups at the ortho position to the azo bridge to yield amine B2 and hydrazo-compound B3. The last peak may be attributed to the reduction of the hydrazo-bond of compound B3 to yields two amines B2 and B4. 
<smiles>CC(=O)Oc1c(N=Nc2scc(-c3ccccc3O)c2C(=O)O)cc(N=Nc2scc(-c3ccccc3O)c2C(=O)O)cc1C(=O)O</smiles><smiles>CC(=O)Oc1c(NNc2scc(-c3ccccc3O)c2C(=O)O)cc(NNc2scc(-c3ccccc3O)c2C(=O)O)cc1C(=O)O</smiles>

B1<smiles>CC(=O)Oc1c(N)cc(NNc2scc(-c3ccccc3O)c2C(=O)O)cc1C(=O)O</smiles><smiles>Nc1scc(-c2ccccc2O)c1C(=O)O</smiles>

B2

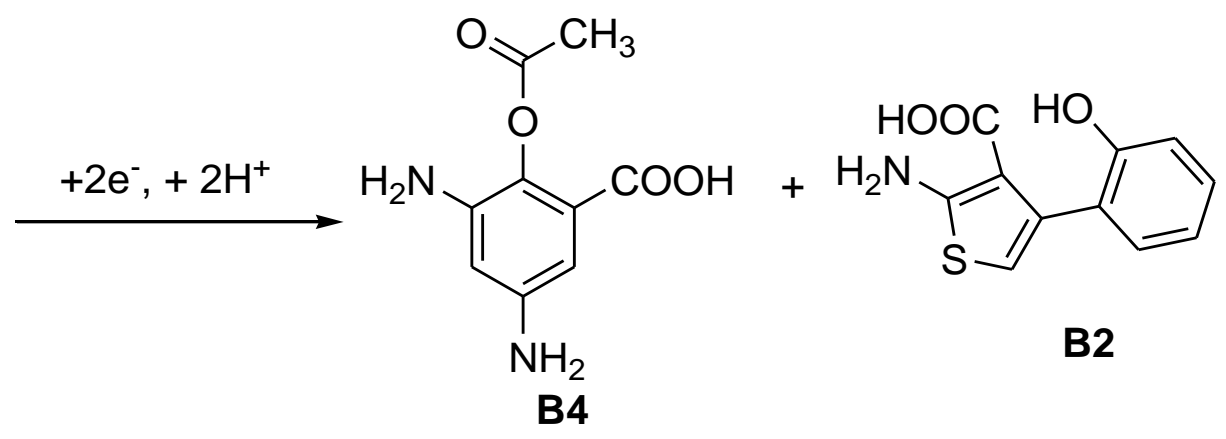

\section{B3}

Scheme 5. Electrochemical reaction mechanism of $\mathbf{5 c}$.

Compound 6. The mechanistic details of the electrochemical oxidation and reduction of compound 6 is indistinguishable with that of compound $\mathbf{5 a}$.<smiles>CC(=O)Oc1c(NNc2cccc(C(=O)O)c2OC(C)=O)cccc1NNc1scc2c1c(=N)oc1ccccc12</smiles> 


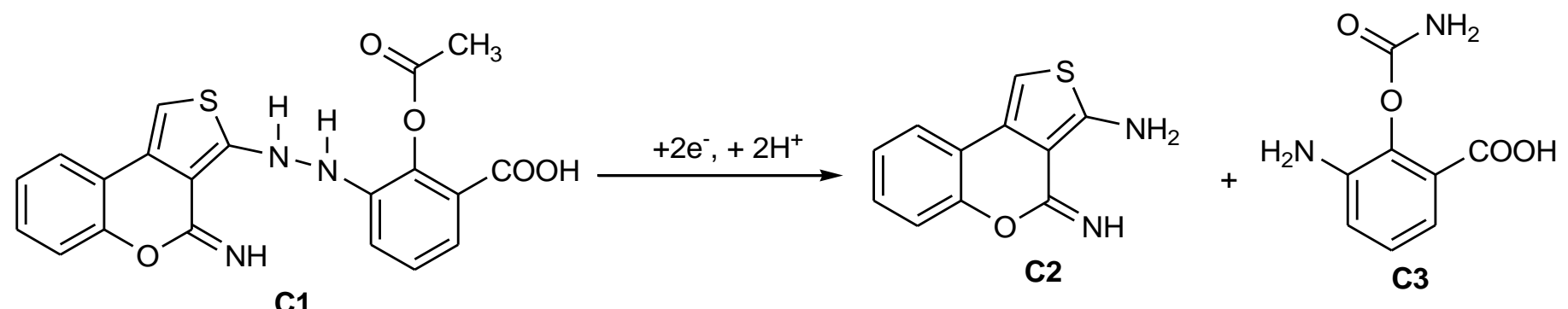

C1

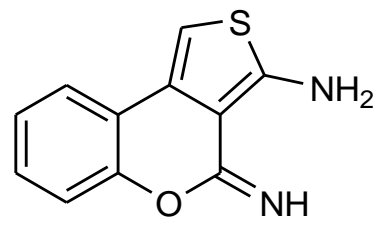

C2

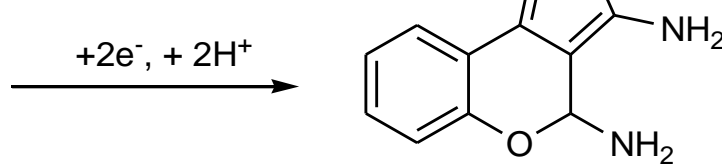

C4

Scheme 6. Electrochemical reaction mechanism of 6 .

\section{Antimicrobial activity}

The antimicrobial activity of azo compounds and phenol derivatives was performed against bacterial and fungal species and their minimum inhibitory concentration (MIC) and minimum microbicidal concentration (MMC) values are summarized in Table 1 . The antimicrobial activities of compounds $\mathbf{1 a}, \mathbf{1} \mathbf{b}, \mathbf{2} \mathbf{a}, \mathbf{2} \mathbf{b}, \mathbf{5 a}, \mathbf{5 b}, \mathbf{5 c}$ and 6 have been recorded on 25\%(3/12), 16.66\%(2/12), 100\%(12/12), 100\%(12/12), 100\%(12/12), $100 \%(12 / 12)$ and $100 \%(12 / 12)$ of the tested microorganisms, respectively. The antibacterial and antifungal activities of the prepared azo compounds $\mathbf{5}$ and $\mathbf{6}$ were higher than those of their starting materials as compounds $\mathbf{1 a}$ and $\mathbf{1 b}$ were not active against all the tested bacterial species (MIC $>256 \mu \mathrm{g} / \mathrm{mL}$ ) whereas they displayed weak antifungal activity (MIC $=64->256 \mu \mathrm{g} / \mathrm{mL}$ ) when compared to that of their derivatives (MIC = $4-256 \mu \mathrm{g} / \mathrm{mL}$ ). Standard drugs ciprofloxacin and nystatin were used as controls for antibacterial and antifungal activities, respectively performed better than most tested compounds (Table 1). Interestingly, compounds $\mathbf{5 a}, \mathbf{5 b}, \mathbf{5 c}$ and $\mathbf{6}$ were in some cases equipotent with standard drugs against B. subtilis, S. aureus, E. coli, V. cholerae NB2 and SG24 and C. neoformans. The activity of each compound varied depending of the microorganism and compound 5a showed the lowest MIC value of $4 \mu \mathrm{g} / \mathrm{mL}$ against $B$. subtilis compared to 8 $\mu \mathrm{g} / \mathrm{mL}$ for the control ciprofloxacin.

Compound $\mathbf{5 a}$ and $\mathbf{5 b}(\mathrm{MIC}=4-32 \mu \mathrm{g} / \mathrm{mL})$ were the most potent against all the bacterial and fungal strains followed in decreasing order by compounds $\mathbf{6}, \mathbf{5 c}, \mathbf{3 a}, \mathbf{3 b}, \mathbf{1 a}$, and $\mathbf{1 b}$. Compound $\mathbf{5 a}$ with two 3-diazenyl-4Hthieno[3,4-c]chromen-4-one moieties at positions -3 and -5 of the phenolic ring, is equipotent with compound 5b against S. aureus ATCC25923, S. aureus, P. aeruginosa ATCC27853, V. cholerae, C. albicans, C. neoformans and $C$. tropicalis. In contrast, compound $\mathbf{5 c}$ with opened coumarin rings of similar substituents at the same positions on the phenolic ring exhibited similar potency as that of compounds $\mathbf{5 a}$ and $\mathbf{5 b}$ against $\boldsymbol{C}$. neoformans and C. tropicalis with MIC values of 4 and $8 \mu \mathrm{g} / \mathrm{mL}$ respectively. A structure-activity-relationship study from the results indicated the necessity of electron withdrawing and releasing groups at different positions on the phenolic ring. So, a combination of electron withdrawing and releasing groups on the phenolic ring can be synthesized and tested with a hope to get promising antimicrobial agents. A lower MMC/MIC ( $\leq 4)$ value signifies that a minimum amount of tested compounds is used to kill the microbial species, whereas, a higher values signifies the use of comparatively higher amount of compound for the control of any microorganism. ${ }^{30}$ Hence, compounds $\mathbf{1 a}$ and $\mathbf{1 b}$ showed fungistatic effect on the sensitive fungal strains while compound 2 a displayed microbicidal activity against S. aureus ATCC25923, S. aureus, B. subtilis, 
P. aeruginosa ATCC27853 and E. coli and bactericidal effect against S. flexneri and V. cholerae. The other compounds exhibited microbicidal effect on all the sensitive microorganisms. The results of the present investigation are in agreement with those reported in the literature describing the antimicrobial activities of some azo compounds and phenol derivatives against a wide range of microorganisms among which $S$. aureus, ${ }^{31-35}$ P. aeruginosa, ${ }^{31-33,36}$ V. cholera, ${ }^{37-40}$ B. subtilis, ${ }^{37-40}$ C. albicans, ${ }^{31,33,36,40}$ C. neoformans ${ }^{36,42-44}$ and $C$. tropicalis. ${ }^{45-48}$.

\section{Cytotoxic activity}

The cytotoxic activity of azo compounds and phenol derivatives against red blood cells (RBCs) was investigated using Triton X-100 as a positive control. The positive control showed about $100 \%$ lysis, whereas the phosphate buffer saline (PBS) showed no lysis of RBCs. Interestingly, none of the tested compounds showed cytotoxic activity against RBCs at concentrations up to $256 \mu \mathrm{g} / \mathrm{mL}$ (results not shown). This finding supports the selective toxicity of the tested compounds towards the tested bacteria.

Table 1. Antibacterial and antifungal activities (in $\mu \mathrm{g} / \mathrm{ml}$ ) of azo compounds and phenol derivatives against bacterial and yeast species

\begin{tabular}{|c|c|c|c|c|c|c|c|c|c|c|}
\hline $\begin{array}{l}\text { Microorga } \\
\text { nisms }\end{array}$ & $\begin{array}{l}\text { Inhibition } \\
\text { parameters }\end{array}$ & $1 a$ & $1 b$ & $2 a$ & $2 b$ & $5 a$ & $5 b$ & $5 c$ & 6 & $\begin{array}{l}\text { Reference } \\
\text { drugs* }\end{array}$ \\
\hline \multicolumn{11}{|l|}{ Bacteria } \\
\hline Staphyloc & MIC & $>256$ & $>256$ & 32 & 64 & 8 & 8 & 16 & 8 & 2 \\
\hline occus & $\mathrm{MBC}$ & $>256$ & $>256$ & 128 & 128 & 16 & 16 & 32 & 16 & 2 \\
\hline aureus & $\mathrm{MBC} / \mathrm{MIC}$ & nd & nd & 4 & 2 & 2 & 2 & 2 & 2 & 1 \\
\hline \multicolumn{11}{|l|}{ ATCC2592 } \\
\hline \multicolumn{11}{|l|}{3} \\
\hline \multirow[t]{3}{*}{ S. aureus } & MIC & $>256$ & $>256$ & 32 & 64 & 4 & 4 & 16 & 8 & 4 \\
\hline & $\mathrm{MBC}$ & $>256$ & $>256$ & 128 & 128 & 8 & 8 & 32 & 16 & 4 \\
\hline & $\mathrm{MBC} / \mathrm{MIC}$ & nd & nd & 4 & 2 & 2 & 2 & 2 & 2 & 1 \\
\hline Bacillus & MIC & $>256$ & $>256$ & 64 & 128 & 4 & 8 & 16 & 8 & 8 \\
\hline \multirow[t]{2}{*}{ subtilis } & $\mathrm{MBC}$ & $>256$ & $>256$ & 128 & 256 & 16 & 16 & 32 & 16 & 8 \\
\hline & $\mathrm{MBC} / \mathrm{MIC}$ & nd & nd & 2 & 2 & 4 & 2 & 2 & 2 & 1 \\
\hline Pseudomo & MIC & $>256$ & $>256$ & 64 & 64 & 8 & 8 & 16 & 8 & 2 \\
\hline nas & $\mathrm{MBC}$ & $>256$ & $>256$ & 128 & 128 & 16 & 16 & 32 & 8 & 2 \\
\hline aeruginos & $\mathrm{MBC} / \mathrm{MIC}$ & nd & nd & 2 & 2 & 2 & 2 & 2 & 1 & 1 \\
\hline \multicolumn{11}{|l|}{$a$} \\
\hline Escherichi & MIC & $>256$ & $>256$ & 64 & 128 & 4 & 8 & 16 & 16 & 4 \\
\hline \multirow[t]{2}{*}{ a coli } & $\mathrm{MBC}$ & $>256$ & $>256$ & 128 & 256 & 16 & 32 & 16 & 32 & 4 \\
\hline & $\mathrm{MBC} / \mathrm{MIC}$ & nd & nd & 2 & 2 & 4 & 4 & 1 & 2 & 1 \\
\hline Shigella & MIC & $>256$ & $>256$ & 128 & 128 & 8 & 16 & 32 & 16 & 4 \\
\hline \multirow[t]{2}{*}{ flexneri } & $\mathrm{MBC}$ & $>256$ & $>256$ & 256 & $>256$ & 16 & 32 & 64 & 32 & 4 \\
\hline & $\mathrm{MBC} / \mathrm{MIC}$ & nd & nd & 2 & nd & 2 & 2 & 2 & 2 & 1 \\
\hline $\begin{array}{l}\text { Vibrio } \\
\text { cholerae }\end{array}$ & MIC & $>256$ & $>256$ & 128 & 128 & 16 & 16 & 64 & 32 & 16 \\
\hline NB2 & & & & & & & & & & \\
\hline
\end{tabular}




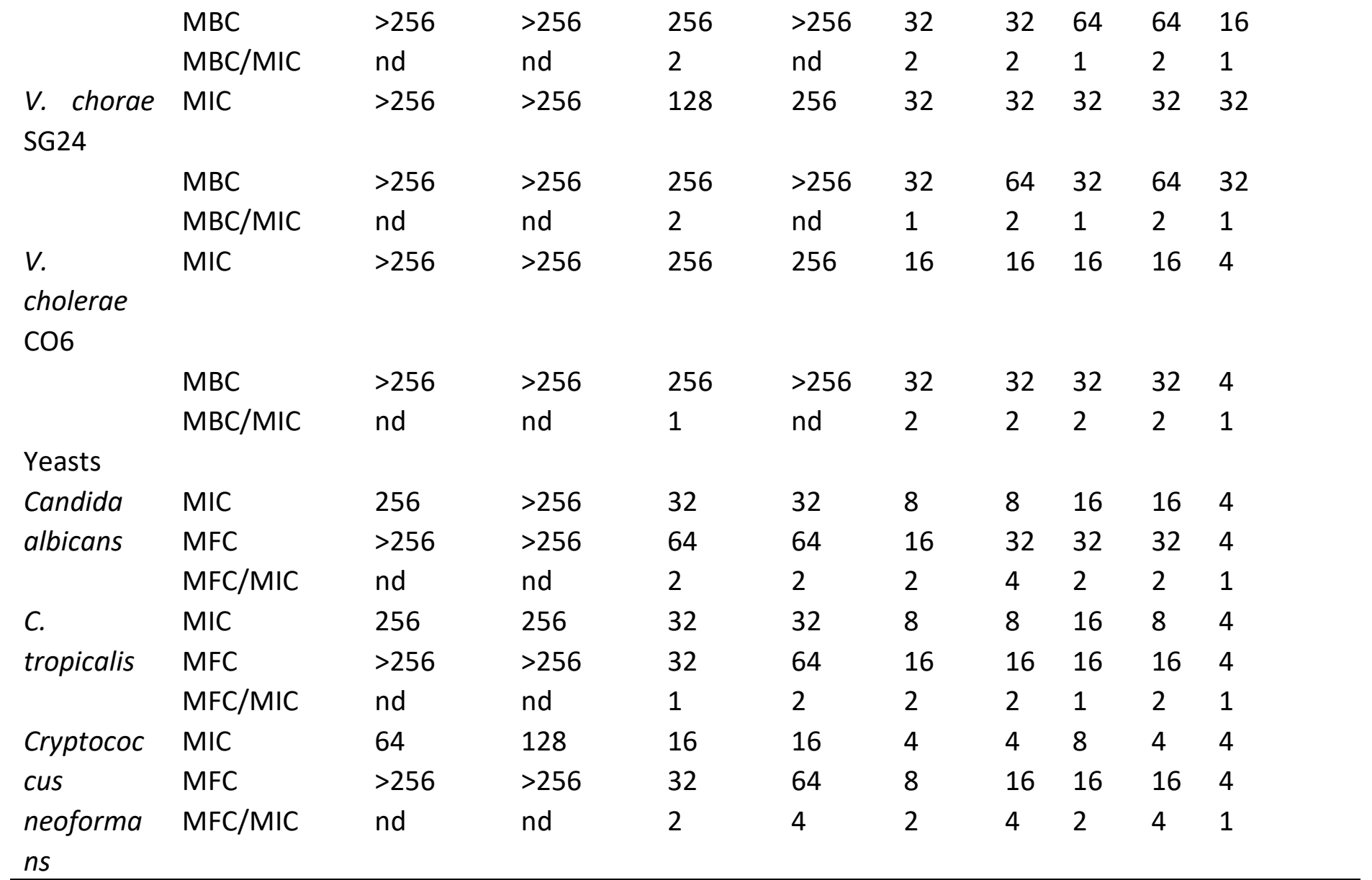

*Ciprofloxacin for bacteria and nystatin for yeasts; nd : not determined. MIC: Minimum Inhibitory Concentrations; MBC: Minimum Bactericidal Concentrations; MFC: Minimum Fungicidal Concentration

\section{Conclusions}

The study of the reactions of the title 2-aminothiophene substrates with the phenolic reagents has confirmed the high reactivity of the intermediate thienyl diazonium ions $\mathbf{3}$ which coupling degree and regio-orientation on the phenolic rings strongly depend on the nature of the substituents initially present. With salicylic acid the electrophilic attack of the diazonium reagent 3 a occurs at substitution free positions -3 and -5 , whereas with paraacetaminophen the electrophilic substitutions took place at positions -2 and -3 and with 2 -acetylsalicylic acid at positions -3 and -5 . In contrast, 2-acetylsalicylic acid undergoes only one electrophilic substitution at position -3 with the intermediate diazonium reagent $\mathbf{3 b}$. All the newly prepared azo dyes where fully characterized by their elemental and spectroscopic data. The electrochemical study on glassy carbon electrode of the new dyestuffs brought further supporting evidences to the structural assignments. The antimicrobial screenings revealed that all the four newly prepared azo dyes $\mathbf{5 a}, \mathbf{5 b}, \mathbf{5} \mathbf{c}$ and $\mathbf{6}$ have prominent antibacterial and antifungal activities. 


\section{Experimental Section}

General. All Melting points are corrected and were determined with a STUART SCIENTIFIC Melting Point Apparatus Model SMP3. The T.L.Cs were carried out on Eastman Chromatogram Silica Gel Sheets (13181; 6060) with fluorescent indicator. A mixture of ethyl acetate and methylene chloride (7:3) was used as eluent and iodine was used as revelator for the chromatograms. The IR spectra were measured with a Fourier Transform Infrared spectrometer Bruker Alpha. The UV spectra were recorded with a JENWAY 6715 UV-Vis Spectrophotometer. Combustion analyses were carried out with a C, H, N, S Euro EA from Hekatech company, their results were found to be in good agreement $( \pm 0.3 \%)$ with the calculated values. EIMS spectra were recorded on a double focusing mass spectrometer (Varian MAT 311A). ${ }^{1} \mathrm{H}-\mathrm{NMR}$ spectra were recorded in DMSO- $d_{6}$ on a Bruker DRX spectrometer operating at $400 \mathrm{MHz} .{ }^{13} \mathrm{C}-\mathrm{NMR}$ spectra were recorded in DMSO- $d_{6}$ on a Bruker DRX spectrometer operating at $100 \mathrm{MHz}$. TMS was used as internal reference. The chemical shifts $(\delta)$ and coupling constants $(\mathrm{J})$ are expressed in ppm and hertz respectively. Carbon attribution determined by ${ }^{13} \mathrm{C}$, HSQC and HMQC experiments.

All the reagents mentioned in this work were purchased from Aldrich and Fluka and were used without further purification. Starting materials $\mathbf{2} \mathbf{a}$ and $\mathbf{2} \mathbf{b}$ have been prepared according to literature procedures as published earlier. ${ }^{22}$

General procedure for the preparation of coupling products $5 \mathrm{a}-\mathrm{c}$ and 6 . Dry sodium nitrite $(2.07 \mathrm{~g}, 3 \mathrm{mmol})$ was slowly added over a period of 30 minutes to concentrated sulphuric acid $(10 \mathrm{~mL})$ with occasional stirring. The solution was cooled to $0-5^{\circ} \mathrm{C}$. Compounds $\mathbf{2 a}$ and $\mathbf{2} \mathbf{b}$ was dissolved in DMSO $(10 \mathrm{~mL})$ and cooled to $0-5^{\circ} \mathrm{C}$. The nitrosyl sulphuric acid solution was added to the solution of $\mathbf{2} \mathbf{a}$ and $\mathbf{2} \mathbf{b}$ and the temperature was maintained to $0-5{ }^{\circ} \mathrm{C}$. The clear diazonium salt solutions thus obtained consisting of the in situ formed intermediates $\mathbf{3} \mathbf{a}$ and $\mathbf{3 b}$, were used immediately in the coupling reactions.

The phenolic coupler ( $3 \mathrm{mmol}) 4 a-c$ was dissolved in DMSO $(10 \mathrm{~mL})$ and then cooled in an ice-bath at 0-5 ${ }^{\circ} \mathrm{C}$. The diazonium solutions of $\mathbf{3 a}$ and $\mathbf{3 b}$ previously prepared were added drop wise over 1 hour, and then $15 \mathrm{~mL}$ of sodium acetate solution (10\%) was added to the mixture. The solid precipitate was collected on a filter and crystallised from water-ethanol ( $50 \% \mathrm{v} / \mathrm{v}$ ) mixture to give the corresponding phenolic thienyl azo dyes.

2-Hydroxy-3,5-bis[2-(4-oxo-4H-thieno[3,4-c]chromen-3-yl)diazenyl]benzoic acid (5a). Compound 5a was obtained as black powder (1.57g, 56\%). mp 192-194 ${ }^{\circ} \mathrm{C}$; Rf 0.55 in $\mathrm{CH}_{2} \mathrm{Cl}_{2} / \mathrm{AcOEt} 80 \% \mathrm{v} / \mathrm{v}$; UV (EtOH) $\lambda_{\max }(\mathrm{LOg} \varepsilon)$ 235 (1.50), 297 (1.59), 335 (2.52), 430 (1.40) nm. IR (solid, KBr, vmax, cm-1): 3567 (free O-H), 3264 (ass O-H), 1731-1670 ( $\mathrm{C}=\mathrm{O}), 1637-1603\left(\mathrm{C}_{\mathrm{Ar}}=\mathrm{C}_{\mathrm{Ar}}\right), 1544-1500$ (thiophenic $\left.\mathrm{C}=\mathrm{C}\right), 1491(-\mathrm{N}=\mathrm{N}-), 1268-1236$ (C-N), 1163-1112 (C-O), 766-756 (= $\left.\mathrm{C}_{\mathrm{Ar}}-\mathrm{H}\right) \mathrm{cm}^{-1} .{ }^{1} \mathrm{H}$ NMR (DMSO- $\left.d_{6}, 400 \mathrm{MHz}\right): \delta_{H} 8.80\left(2 \mathrm{H}, \mathrm{dd}, J_{H H} 7.5\right.$ and 1.7, Hz, H-9', H-9') ), $7.72\left(1 \mathrm{H}, \mathrm{d}, J_{H H} 1.2 \mathrm{~Hz}, \mathrm{H}-6\right), 7.70\left(2 \mathrm{H}, \mathrm{s}, \mathrm{H}-1^{\prime}, \mathrm{H}-1^{\prime \prime}\right), 7.69\left(2 \mathrm{H}\right.$, ddd, $J_{H H} 7.5 J_{H H} 6.4$ and $\left.1.5 \mathrm{~Hz}, \mathrm{H}-7^{\prime}, \mathrm{H}-7^{\prime \prime}\right), 7.39$ $\left(2 \mathrm{H}, \mathrm{ddd}, J_{H H} 7.3 J_{H H} 6.9\right.$ and $\left.1.6 \mathrm{~Hz}, \mathrm{H}-8^{\prime}, \mathrm{H}-8^{\prime \prime}\right), 7.37\left(1 \mathrm{H}, \mathrm{d}, J_{H H} 1.2 \mathrm{~Hz}, \mathrm{H}-4\right), 7.35\left(2 \mathrm{H}, \mathrm{dd}, J_{H H} 6.8,1.1 \mathrm{~Hz}, \mathrm{H}-6^{\prime}\right.$, H-6"'). ${ }^{13} \mathrm{C}$ NMR (DMSO-d6, $100 \mathrm{MHz}$ ): $\delta_{C} 184.1(\mathrm{COOH}), 162.8$ (C-4', C-4”); 156.9 (C-3', C-3"); 155.4 (C-5a', C5a"); 153.6 (C-9b', C-9b"), 154,4 (C-2); 148,7 (C-3a', C-3a”); 135.5 (C-6); 135.4 (C-7', C-7'); 129.9 (C-9', C-9”), 126.1 (C-8', C-8"');125.6 (C-1', C-1"'); 119.5 (C-5), 118.2 (C-9a', C-9a'”); 117.7 (C-6', C-6"'), 117.4 (C-4), 113,5 (C1), 102.4 (C-3). ESIMS m/z (\%) 607 (1), 549 (1), 502 (8), 493(1), 413 (1), 384 (5), 360 (19), 322 (1), 320 (4), 292 (5), 270 (100), 248 (1), 228 (1), 208 (20). Anal. Calcd. for $\mathrm{C}_{29} \mathrm{H}_{14} \mathrm{~N}_{4} \mathrm{O}_{7} \mathrm{~S}_{2}: \mathrm{C}, 58.58 ; \mathrm{H}, 2.37 ; \mathrm{N}, 9.42 ; \mathrm{S}, 10.79$. Found: C, 58.55; H, 2.39; N, 9.45; S, 10.81.

$\mathbf{N}$-\{4-Hydroxy-2.3-bis[2-(4-oxo-4H-thieno[3,4c]chromen-3-yl)diazenyl]phenyl\} acetamide (5b). Compound 5b was obtained as grey powder $(0.93 \mathrm{~g}, 34 \%)$. $\mathrm{mp} 168-170{ }^{\circ} \mathrm{C}$. Rf 0.57 in $\mathrm{CH}_{2} \mathrm{Cl}_{2} / \mathrm{AcOEt} 80 \% \mathrm{v} / \mathrm{v}$; UV (EtOH) $\lambda_{\max }(\log \varepsilon) 235$ (1.26), 296 (1.21), 334 (1.00), 355 (0.98), 360 (0.86), 420 (1.21) nm; IR (solid, KBr, vmax, cm ${ }^{-1}$ ): 
3545 (O-H), 3134 (N-H), 1726 (C=O), 1598 (C=C), 1290 (C-O) 1213 (C-N) 1490 (N=N) cm-1. ${ }^{1} \mathrm{H}$ NMR (DMSO-d6, $400 \mathrm{MHz}): \delta_{H} 8.82\left(2 \mathrm{H}, \mathrm{dd}, J_{H H} 8.1\right.$ and $\left.1.2 \mathrm{~Hz}, \mathrm{H}-9^{\prime}, \mathrm{H}-9^{\prime \prime}\right), 7.74\left(2 \mathrm{H}, \mathrm{s}, \mathrm{H}-1^{\prime}, \mathrm{H}-1^{\prime \prime}\right), 7.71\left(2 \mathrm{H}, \mathrm{ddd}, J_{H H} 7.5 J_{H H} 7.2\right.$ and $\left.1.6 \mathrm{~Hz}, \mathrm{H}-7^{\prime}, \mathrm{H}-7^{\prime \prime}\right), 7.53\left(1 \mathrm{H}, \mathrm{d}, J_{H H} 7.2 \mathrm{~Hz}, \mathrm{H}-6\right), 7.45\left(2 \mathrm{H}\right.$, ddd, $J_{H H} 7.4 J_{H H} 6.6$ and $\left.1.5 \mathrm{~Hz}, \mathrm{H}-8^{\prime}, \mathrm{H}-8^{\prime \prime}\right), 7.39$ $\left(2 \mathrm{H}, \mathrm{dd}, J_{H H} 8.9\right.$ and $\left.1.4 \mathrm{~Hz}, \mathrm{H}-6^{\prime}, \mathrm{H}-6^{\prime \prime}\right), 7.37\left(1 \mathrm{H}, \mathrm{d}, J_{H H} 7.3 \mathrm{~Hz}, \mathrm{H}-5\right), 2.80\left(3 \mathrm{H}, \mathrm{s}, \underline{\mathrm{CH}}_{3}\right) .{ }^{13} \mathrm{C}$ NMR (DMSO- $d_{6}, 100$ $\mathrm{MHz}): \delta_{C} 162.9\left(\mathrm{CH}_{3} \underline{\mathrm{C}}=\mathrm{O}\right), 162.9\left(\mathrm{C}-4^{\prime}, \mathrm{C}-4^{\prime \prime}\right) ; 157.0$ (C-4), 155.4 (C-3', C-3"), $154.5(\mathrm{C}-1), 153.3\left(\mathrm{C}-9 \mathrm{~b}^{\prime}, \mathrm{C}-9 \mathrm{~b}^{\prime \prime}\right)$,

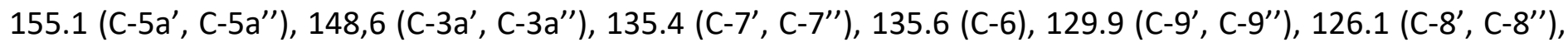
125.6 (C-1"', C-1'), 118.2 (C-9a', C-9a'), 117.7 (C-6', C-6"'), 117.4 (C-3), 113.5 (C-2), 102,3 (C-5), 18.4 (C(O) $\left.\mathrm{CH}_{3}\right)$. ESIMS m/z (\%) 607 (1), 552 (1), 521 (2), 517 (5), 493 (3), 413 (1), 384 (2), 360 (9), 284 (3), 270 (100), 228 (3), 208 (29), 189 (2). Anal. Calcd. for $\mathrm{C}_{30} \mathrm{H}_{17} \mathrm{~N}_{5} \mathrm{O}_{6} \mathrm{~S}_{2}$ : C, 59.30; $\mathrm{H}, 2.82 ; \mathrm{N}, 11.53 ; \mathrm{S}, 10.55$. Found: C, 59.18; $\mathrm{H}, 2.79$; $\mathrm{N}, 11.52 ; \mathrm{S}, 10.52$.

\section{2-[2-(2-Acetyloxy)-3-carboxy-5-\{2-carboxy-4-(2-hydroxphenyl)-2-thienyl]\}phenyl)diazenyl]-4-(2-}

hydroxyphenyl)-3-thiophenecarboxylic acid (5c). Compound 5c was obtained as black powder (1.79 g, 58\%). $\mathrm{mp}>250{ }^{\circ} \mathrm{C}$. Rf 0.55 in $\mathrm{CH}_{2} \mathrm{Cl}_{2} /$ AcOEt 80\% v/v; UV (EtOH) $\lambda_{\max }(\log \varepsilon) 235$ (1.41), 305 (1.39), 330 (1.42) nm. IR (solid, $\mathrm{KBr}$, vmax, cm $\mathrm{cm}^{-1}$ ): 3621-3500 (free O-H), 3500-3277 (ass O-H), 2291 (=C-H), 1706 (C=O), 1603-1590 $\left(\mathrm{C}_{\mathrm{Ar}}=\mathrm{C}_{\mathrm{Ar}}\right), 1540-1523$ (thiophenic $\left.\mathrm{C}=\mathrm{C}\right), 1490(-\mathrm{N}=\mathrm{N}-), 1371-1234(\mathrm{C}-\mathrm{O}), 1194-1110(\mathrm{C}-\mathrm{N}), 752\left(=\mathrm{C}_{\mathrm{Ar}}-\mathrm{H}\right) \mathrm{cm}^{-1} .{ }^{1} \mathrm{H}$ NMR (DMSO- $\left.d_{6}, 400 \mathrm{MHz}\right): \delta_{H} 8.73\left(1 \mathrm{H}, \mathrm{d}, J_{H H} 1.3 \mathrm{~Hz}, \mathrm{H}-4^{\prime \prime}\right), 8.01\left(2 \mathrm{H}\right.$, ddd, $J_{H H} 1.7 J_{H H} 6.9$ and $8.6 \mathrm{~Hz}, \mathrm{H}-4^{\prime}, \mathrm{H}-$ $\left.4^{\prime \prime \prime \prime \prime}\right), 7.99\left(1 \mathrm{H}, \mathrm{d}, J_{H H} 1.3 \mathrm{~Hz}, \mathrm{H}-6^{\prime \prime}\right), 7.83\left(2 \mathrm{H}, \mathrm{dd}, J_{H H} 1.1\right.$ and $\left.7.8 \mathrm{~Hz}, \mathrm{H}-6^{\prime}, \mathrm{H}-6^{\prime \prime \prime \prime \prime}\right), 7.80\left(2 \mathrm{H}, \mathrm{dd}, J_{H H} 7.8\right.$ and 8.5 $\left.\mathrm{Hz}, \mathrm{H}-5^{\prime}, \mathrm{H}-5^{\prime \prime \prime \prime \prime}\right), 7.73\left(2 \mathrm{H}, \mathrm{dd}, \mathrm{J}_{H H} 1.3\right.$ and $\left.6.9 \mathrm{~Hz}, \mathrm{H}-3^{\prime}, \mathrm{H}-3^{\prime \prime \prime \prime \prime}\right), 7.56\left(2 \mathrm{H}, \mathrm{s}, \mathrm{H}-5, \mathrm{H}-5^{\prime \prime \prime}\right), 2.74\left(3 \mathrm{H}, \mathrm{s}, \mathrm{C}(\mathrm{O}) \underline{\mathrm{C}} \mathrm{H}_{3}\right) .{ }^{13} \mathrm{C}$ NMR (DMSO-d, $100 \mathrm{MHz}): \delta_{C} 184.0(3 \mathrm{COOH}), 164.5\left(\underline{\mathrm{COCH}}_{3}\right), 154.9\left(\mathrm{C}-2^{\prime}, \mathrm{C}-2^{\prime \prime \prime \prime}\right), 154.8\left(\mathrm{C}-2^{\prime \prime}\right), 153.7$ (C-2, C-

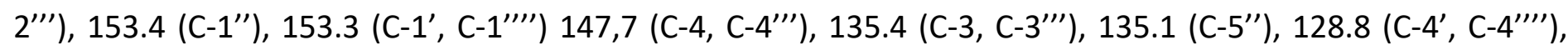

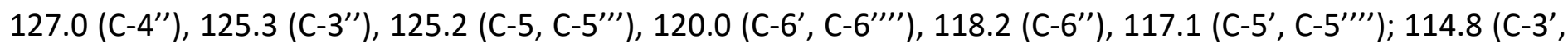
C-3"'”'), 18.1; $\left(\mathrm{CH}_{3}\right)$. ESIMS m/z (\%) 675 (1), 628 (3), 535 (3), 517 (3), 493 (3), 413 (1), 390 (6), 338 (6), 284 (5), 270 (100), 248 (16), 208 (7), 186 (15). Anal. Calcd. for $\mathrm{C}_{31} \mathrm{H}_{20} \mathrm{~N}_{4} \mathrm{O}_{10} \mathrm{~S}_{2}$ : C, 55.35; H, 3.00; N, 8.33; S, 9.53; S, 14.05. Found: C, 55.38; H, 2.98; N, 8.30; S, 13.98.

2-(Acetyloxy)-3-[2-(4imino-4H-thieno[4,3-c]chromen-3-yl)diazenyl]benzoic acid (6). Compound 6 was obtained as brown powder (1.35 g, 41\%). mp 224-226 ${ }^{\circ} \mathrm{C}$. Rf 0.55 in $\mathrm{CH}_{2} \mathrm{Cl}_{2} / \mathrm{AcOEt}$ 80\%); UV (EtOH) $\lambda_{\max }(\log \varepsilon)$ 235 (1.28), 275 (1.05), 335 (0.81), 360 (0.81), 420 (0.99) nm. IR (solid, KBr, vmax, cm-1): $3562(0-H), 3324-3200$ $(\mathrm{N}-\mathrm{H}), 2640-2747(=\mathrm{C}-\mathrm{H}) 1733(\mathrm{C}=\mathrm{O}), 1713(\mathrm{C}=\mathrm{N}), 1605-1598(\mathrm{C}=\mathrm{C}), 1547-1500$ (thiophenic $\mathrm{C}=\mathrm{C}), 1490(-\mathrm{N}=\mathrm{N}-$ ), 1273-1290 (N-H), 1060-1200 (C=O), $764\left(=\mathrm{C}_{\mathrm{Ar}}-\mathrm{H}\right) \mathrm{cm}^{-1} .{ }^{1} \mathrm{H}$ NMR (DMSO-d, $\left.400 \mathrm{MHz}\right): \delta_{H} 9.51(2 \mathrm{H} ; \mathrm{s} ;=\mathrm{NH}) ; 8.82$ $\left(1 \mathrm{H}, \mathrm{dd}, J_{H H} 7.9\right.$ and $\left.1.3 \mathrm{~Hz}, \mathrm{H}-9^{\prime}\right), 7.88\left(1 \mathrm{H}, \mathrm{dd}, J_{H H} 7.9\right.$ and $\left.1.3 \mathrm{~Hz}, \mathrm{H}-6\right), 7,73\left(1 \mathrm{H}, \mathrm{ddd}, J_{H H} 7.3 J_{H H} 6.5\right.$ and 1.5 $\left.\mathrm{Hz}, \mathrm{H}-7^{\prime}\right), 7.49\left(1 \mathrm{H}, \mathrm{dd}, J_{H H} 7.0\right.$ and $\left.1.1 \mathrm{~Hz}, \mathrm{H}-6^{\prime}\right), 7.40\left(1 \mathrm{H} ; \mathrm{s}, \mathrm{H}-1^{\prime}\right), 7.39$ (ddd, $J_{H H} 7.2 J_{H H} 6.7$ and $\left.1.6 \mathrm{~Hz}, \mathrm{H}-8^{\prime}\right)$, $6.96\left(1 \mathrm{H}, \mathrm{dd}, J_{H H} 7.9\right.$ and $\left.8.3 \mathrm{~Hz}, \mathrm{H}-5\right), 6.89\left(1 \mathrm{H}, \mathrm{dd}, J_{H H} 8.3\right.$ and $\left.0.9 \mathrm{~Hz}, 1 \mathrm{H}, \mathrm{H}-4\right), 2.74\left(3 \mathrm{H}, \mathrm{s}, \mathrm{CH}_{3}\right) .{ }^{13} \mathrm{C} \mathrm{NMR}$ (DMSO- $\left.d_{6}, 100 \mathrm{MHz}\right): \delta_{\mathrm{C}} 183.8(\underline{\mathrm{COOH}}), 161.8\left(\mathrm{COCH}_{3}\right), 157.3\left(\mathrm{C}-4^{\prime}\right), 155.5\left(\mathrm{C}-5 \mathrm{a}^{\prime}\right), 155.1\left(\mathrm{C}-9 \mathrm{~b}^{\prime}\right), 154.4\left(\mathrm{C}-3^{\prime}\right)$, 154.2 (C-3a'), 148.9 (C-2), 135.8 (C-1), 135.6 (C-7'), 130.7 (C-6), 129.9 (C-9'), 125.4 (C-8'), 119.7 (C-1'), 119.2 (C4), 117.4 (C-6'), 117.3 (C-5), 115.8 (C-9a'), 112.4 (C-3), 18.2 (C(O)CH3). ms: (ESI $\left.{ }^{+}\right)$m/z (\%) 384 (17), 360 (100), 338 (21), 301 (8), 284 (14), 270 (68). Anal. Calcd. for $\mathrm{C}_{20} \mathrm{H}_{13} \mathrm{~N}_{3} \mathrm{O}_{5} \mathrm{~S}: \mathrm{C}, 58.96 ; \mathrm{H}, 3.22 ; \mathrm{N}, 10.31 ; \mathrm{S}, 7.87$. Found: C, 58.98; H, 3.25; N, 10.28; S, 7.85.

Cyclic voltammetry. A PalmSens type 3 potenstiostat running with PSTrace 4.4 software, supplied by PalmSens BV, Houten (The Netherlands) was used for the cyclic voltammetric (CV) measurements. A standard single compartment three electrode cell was used with an Ag pseudo-reference electrode and a stainless steel rod counter electrode. The working electrode was a glassy carbon electrode (GCE). All electrochemical experiments were carried out without degassing the supporting electrolyte solution. 
Electrochemical procedure. The dyes used were dissolved in dimethylsulfoxide (DMSO). Cyclic voltammograms were recorded in the potential range from $-1.5 \mathrm{~V}$ to $+0.5 \mathrm{~V}$ by transferring the GCE into a 0.05 $\mathrm{M} \mathrm{H}_{2} \mathrm{SO}_{4}$ solution containing an azo dye at a given concentration. The potential scan rate was varied.

Tested microorganisms. The antimicrobial activity was performed against nine bacterial and three fungal species. The selected microorganisms were the Gram-positive (Staphylococcus aureus ATCC25923, S. aureus, Bacillus subtilis) and Gram-negative (Pseudomonas aeruginosa ATCC27853, Escherichia coli S2(1), Shigella flexneri SDINT, Vibrio cholerae NB2, V. cholerae SG24, V. cholerae CO6) bacteria and yeast strains of Candida albicans ATCC10231, C. tropicalis PK233 and Cryptococcus neoformans H99. These microorganisms were taken from our laboratory collection. The fungal and bacterial strains were grown at $37{ }^{\circ} \mathrm{C}$ and maintained on Sabouraud Dextrose Agar (SDA, Conda, Madrid, Spain) and nutrient agar (NA, Conda) slants respectively.

Determination of Minimum Inhibitory Concentration (MIC) and Minimum Microbicidal Concentration (MMC). The antibacterial and antifungal activities were evaluated by determining the MICs and MMCs as previously described. ${ }^{49}$ MICs of azo compounds and phenol derivatives were determined by broth micro dilution method. Each test sample was dissolved in dimethylsulfoxide (DMSO) to give a stock solution. This was serially diluted two-fold in Mueller-Hinton Broth (MHB) for bacteria and Sabouraud Dextrose Broth (SDB) for yeasts to obtain a concentration range of 512 to $0.25 \mu \mathrm{g} / \mathrm{mL}$. Then, $100 \mu \mathrm{L}$ of each sample concentration was added to respective wells (96-well micro plate) containing $90 \mu \mathrm{L}$ of SDB/ MHB and $10 \mu \mathrm{L}$ of inoculum to give final concentration ranges of 256 to $0.125 \mu \mathrm{g} / \mathrm{mL}$. The final concentrations of microbial suspensions were $2.5 \times 10^{5}$ cells $/ \mathrm{mL}$ for yeasts and $10^{6} \mathrm{CFU} / \mathrm{mL}$ for bacteria. Dilutions of nystatin (Sigma-Aldrich, Steinheim, Germany) and ciprofloxacin (Sigma-Aldrich, Steinheim, Germany) were used as positive controls for yeasts and bacteria respectively. Broth with $10 \mu \mathrm{L}$ of DMSO was used as negative control. MICs were assessed visually and were taken as the lowest sample concentration at which there was no growth or virtually no growth. The lowest concentration that yielded no growth after the sub-culturing was considered as the MMCs. ${ }^{49}$ All the tests were performed in triplicate.

Cytotoxicity assay. Whole blood $(10 \mathrm{~mL})$ from albino rats was collected by cardiac puncture in EDTA tubes. The study was conducted according to the ethical guidelines of the Committee for Control and Supervision of Experiments on Animals (Registration no. 173/CPCSEA, dated 28 January, 2000), Government of India, on the use of animals for scientific research. Erythrocytes were harvested by centrifugation at room temperature for $10 \mathrm{~min}$ at $1000 \mathrm{xg}$ and were washed three times in PBS buffer. ${ }^{50}$ The cytotoxicity was performed as previously described..$^{50}$

\section{Acknowledgements}

Emmanuel Sopbué Fondjo gratefully acknowledges the financial support from DAAD (grant $N^{\circ}$ 91691265). Additional financial supports for the work were obtained from the University of Dschang's research grant committee and the Cameroonian Ministry of Higher Education special research allocation.

\section{Supplementary Material}

Electronic Supplementary Information (ESI) available: copies of the ${ }^{1} \mathrm{H}$ and ${ }^{13} \mathrm{C}$ NMR spectra and cyclic voltammograms for all new compounds 


\section{References}

1. Pan, H.; Gao, X.; Zhang, Y.; Prasad, P. N.; Reinhardt, B.; Kannan, R. Chem. Mater. 1995, 7, 816-821. https://doi.org/10.1021/cm00053a002

2. Chemla, D. S.; Zyss, J. Nonlinear optical properties of organic molecules and crystals; Academic Press, Orlando, USA, 1987.

3. Qiu, F. X.; Cao, Y. L.; Xu, H. L.; Jiang, Y.; Zhou, Y. M.; Liu, J. Z. Dyes Pigm. 2007, 75, 454-459. https://doi.org/10.1016/i.dyepig.2006.06.037

4. Fuh, A. Y.-G.; Lin, H.-C.; Mo, T.-S.; Chen, C.-H. Opt. Express 2005, 13, 10634-10641 https://doi.org/10.1364/OPEX.13.010634

5. Lee, M.-R.; Wang, J.-R.; Lee, C.-R.; Fuh, A. Y.-G. Appl. Phys. Lett. 2004, 85, 5822-5824. https://doi.org/10.1063/1.1836864

6. Prasad, P. N.; Williams, D. J. Introduction to Nonlinear Optical Effects in Molecules and Polymers; Wiley: New York, 1991.

7. Marder, S. R.; Perry, J. W. Science 1994, 263, 1706-1707. https://doi.org/10.1126/science.263.5154.1706

8. Shridhar, A. H.; Keshavayya, J.; Hoskeri, J. H. Int J Pharm Pharm Sci. 2002, 4, 386-390.

9. Chakraborti, N.; Bhuiya, S.; Chakraborty, A.; Das. S. Indian J. Chem. 2018, 57A, 59-65.

10. Razus, A. C.; Birzan, L.; Surugiu, N. M.; Corbu, A. C.; Chiraleu, F. Dyes Pigm. 2007, 74, 26-33. https://doi.org/10.1016/i.dyepig.2006.01.041

11. Matsui, M.; Kushida, M.; Funabiki, K.; Shibata, K.; Muramatsu, H.; Hirota, K.; Hosoda, M.; Tai, K. Dyes Pigm. 1998, 37, 283-289. https://doi.org/10.1016/S0143-7208(97)00086-7

12. Belmar, J.; Parra, M.; Zúñiga, C.; Pérez, C.; Muñoz, C. Liq. Cryst. 1999, 26, 389-396. https://doi.org/10.1080/026782999205164

13. Salvador, M. A.; Reis, L. V.; Almeida, P.; Santos, P. F. Tetrahedron 2008, 64, 299-303. https://doi.org/10.1016/i.tet.2007.11.004

14. Alaa, S. A.; Tarek, H. A. Dyes Pigm. 2006, 70, 8-17. https://doi.org/10.1016/i.dyepig.2005.03.004

15. Sabnis, R. W.; Rangnegar, D. W.; Sonawane, N. D. J. Heterocycl. Chem. 1999, 36, 333-345. https://doi.org/10.1002/jhet.5570360203

16. Malik, W.U.; Goyal, R. N.; Jain, R. J. Electroanal. Chem. Interfacial Electrochem. 1978, 87, 129-135. https://doi.org/10.1016/S0022-0728(78)80387-8

17. Xu, G.; O’Dea, J. J.; Osteryoung, J. G. Dyes Pigm. 1996, 30, 201-223. https://doi.org/10.1016/0143-7208(95)00074-7

18. Tsemeugne, J.; Fondjo, E. S.; Tamokou, J.-de-D.; Tonle, I.; Kengne, I. C.; Ngongang, A. D.; Lacmata, S. T.; Rohand, T.; Kuiate, J. R.; Sondengam, B. L. Chem Cent J 2017 doi:10.1186/s13065-017-0345-6. https://doi.org/10.1186/s13065-017-0345-6

19. Yu, J.; Jia, J.; Mab, Z. J Chin Chem Soc. 2004, 51, 1319-1324. https://doi.org/10.1002/jccs.200400191

20. Gewald, K. Angew. Chem. 1961, 73, 114-115. https://doi.org/10.1002/ange.19610730311

21. Gewald, K. Chem. Ber. 1965, 98, 3571-3577. https://doi.org/10.1002/cber.19650981120 
22. Fondjo, S. E.; Döpp, D.; Henkel, G. Tetrahedron 2006, 62, 7121-7131. https://doi.org/10.1016/j.tet.2006.04.037

23. Sopbue, F. E.; Tsemeugne, J.; Tamokou, J.-de-D.; Ngongang, D. A.; Kuiate, J. R.; Sondengam, B. L. Heterocycl. Commun. 2013, 19, 253-259.

24. Sopbue, F. E.; Djeukoua, D. K. S.; Tamokou, J-de-D.; Tsemeugne, J.; Kouamo, S.; Ngouanet, D.; Chouna, J. R.; Nkeng-Efouet-Alango, P.; Kuiate, J. R.; Djintchui, N. A.; Sondengam, B. L. Open Med Chem J. 2016, 10, 21-32.

25. Raposo, M. M. M.; Sousa, A. M. R. C.; Kirsch, G.; Cardoso, P.; Belsley, M.; Gomes, E.deM.; Fonseca, A. M. C. Org. Lett. 2006, 8, 3681-3684.

https://doi.org/10.1021/ol061277s

26. Fondjo, S. E.; Tsemeugne, J.; Sondengam, B. L.; Oppenlaender, T.; Wabo, K. H.; Tane, P.; Connolly, J. D.; Dehaen, W.; Rohand, T.; Kikuchi, H.; Oshima, Y. J. Heterocycl. Chem. 2011, 48, 1295-1301. https://doi.org/10.1002/ihet.757

27. Tsemeugne, J.; Sopbué, F. E.; Djintchui, A. N.; Sabnis, R.W.; Sondengam, B. L. Trends Org. Chem. 2017, 18, 55-69.

28. Surucu, O.; Abaci, S.; Seferoğlu, Z. Electrochim. Acta 2016, 195, 175-183.

https://doi.org/10.1016/i.electacta.2016.02.142

29. Surucu, O.; Bolat, G.; Abaci, S. Talanta, 2017, 168, 113-120.

https://doi.org/10.1016/i.talanta.2017.03.033

30. Djouossi, M. G.; Tamokou, J-de-D.; Ngnokam, D.; Kuiate, J. R.; Tapondjou, A. L.; Harakat, D.; Nazabadioko, L. V. BMC Complement Altern Med. 2015, 15, 1-8.

https://doi.org/10.1016/i.talanta.2017.03.033

31. İspir, E. Dyes Pigm. 2009, 82, 13-19.

https://doi.org/10.1016/i.dyepig.2008.09.019

32. Öztürk, A.; Meysun, I. A. Sci Total Environ. 2006, 358, 137-142.

https://doi.org/10.1016/j.scitotenv.2005.08.004

33. Rauha, J-P.; Remes, S.; Heinonen, M.; Hopia, A.; Kahkonen, M.; Kujala, T.; Pihlaja, K.; Vuorela, H.; Vuorela, P. Int. J. Food Microbiol. 2000, 56, 3-12.

https://doi.org/10.1016/S0168-1605(00)00218-X

34. Dorman, H. J. D.; Deans, S. G. J. Appl. Microbiol. 2000, 88, 308-316.

https://doi.org/10.1046/i.1365-2672.2000.00969.x

35. Clark, A. M.; El-Feraly, A. S.; Li, W.-S. J. Pharm. Sci. 1981, 70, 951-952.

https://doi.org/10.1002/ips.2600700833

36. Pereira, J. A.; Oliveira, I.; Sousa, A.; Valenta o, P.; Andrade, P. B.; Ferreira, I. C. F. R.; Ferreres, F.; Bento, A.; Seabra, R.; Estevinho, L. Food Chem. Toxicol. 2007, 45, 2287-2295.

https://doi.org/10.1016/i.fct.2007.06.004

37. Tsemeugne, J.; Fondjo, E. S.; Tamokou, J.-de-D.; Rohand, T.; Ngongang, A. D.; Kuiate, J. R.; Sondengam, B. L. Int J Med Chem. 2018 doi: 10.1155/2018/9197821.

https://doi.org/10.1155/2018/9197821

38. Tamokou, J.-de-D.; Tsemeugne, J.; Fondjo, E. S.; Sarkar, P.; Kuiate, J. R.; Djintchui, A. N.; Sondengam, B. L.; Bag, P. K. Pharmacologia 2016, 7, 182-192.

https://doi.org/10.5567/pharmacologia.2016.182.192

39. Rattanachaikunsopon, P.; Phumkhachorn, P. J. Biosci. Bioeng. 2010, 110, 614-619.

https://doi.org/10.1016/i.jbiosc.2010.06.010 
40. Mahboubi, A.; Kamalinejad, M.; Ayatollahi, A. M.; Babaeianb, M. Iran J. Pharm. Res. 2014, 13, 559-566.

41. Odabasog`lu, M.; Albayrak, Ç.; O”zkanca, R.; Aykan, F. Z.; Lonecke, P. J. Mol. Struct. 2007, 840, 71-89. https://doi.org/10.1016/i.molstruc.2006.11.025

42. Daidone, G.; Maggio, B.; Plescia, S.; Raffa, D.; Musiu, C.; Milia, C.; Perra, G.; Marongiu, M. E. Eur. J. Med. Chem. 1998, 33, 375-382.

https://doi.org/10.1016/S0223-5234(98)80004-4

43. Dembitsky, V. M.; Gloriozova, T. A.; Poroikov, V. V. Nat. Prod. Bioprospect. 2017, 7, 151-169. https://doi.org/10.1007/s13659-016-0117-3

44. Barros, L.; Calhelha, R. C.; Vaz, J. A.; Ferreira, I. C. F. R.; Baptista, P.; Estevinho, L. M. Eur Food Res Technol 2007, 225, 151-156.

https://doi.org/10.1007/s00217-006-0394-x

45. Sivakumar, P. M.; Kumar, T. M.; Doble, M. Chem. Biol. Drug Des. 2009, 74, 68-79.

https://doi.org/10.1111/i.1747-0285.2009.00828.x

46. Musiol, R.; Jampilek, J.; Buchta, V.; Silva, L.; Niedbala, H.; Podeszwa, B.; Palka, A.; Majerz-Maniecka, K.; Oleksyn, B.; Polanski, J. Bioorg. Med. Chem. 2006, 14, 3592-3598.

https://doi.org/10.1016/j.bmc.2006.01.016

47. Pina-Vaz, C.; Rodrigues, A. G.; Pinto, E.; Costa-de-Oliveira, S.; Tavares, C.; Salgueiro, L.; Cavaleiro, C.; Gonçalves, M. J.; Martinez-de-Oliveira, J. J. Eur. Acad. Dermatol. Venereol. 2003, 18, 73-78. https://doi.org/10.1111/j.1468-3083.2004.00886.x

48. Gallucci, M. N.; Carezzano, M. E.; Oliva, M. M.; Demo, M. S.; Pizzolitto, R. P.; Zunino, M. P.; Zygadlo, J. A.; Dambolena, J. S. J. Appl. Microbiol. 2014, 116, 795-804.

https://doi.org/10.1111/jam.12432

49. Tamokou, J.-de-D.; Tala, F. M.; Wabo, K. H.; Kuiate, J. R.; Tane, P. J. Ethnopharmacol. 2009, 124, 571-575. https://doi.org/10.1016/i.jep.2009.04.062

50. Situ, H. ; Bobek, LA. Antimicrob Agents Chemother. 2000, 44, 1485-1493.

https://doi.org/10.1128/AAC.44.6.1485-1493.2000 